\section{Use of pulsed electric fields to induce breakage of glandular trichome cells in leaves of fresh patchouli (Pogostemon cablin Benth.): Specific energy input consumption}

Sukardi Sukardi, ${ }^{1}$ Sudjito Soeparman, Bambang Dwi Argo, ${ }^{3}$ Yudy Surya Irawan ${ }^{2}$

${ }^{1}$ Department of Agricultural Industrial Technology, Faculty of Agricultural Technology, ${ }^{2}$ Department of Mechanical Engineering, Faculty of Engineering, ${ }^{3}$ Department of Agricultural Engineering, Faculty of Agricultural Technology, Brawijaya University, East Java, Indonesia

\begin{abstract}
Research has been performed using a pulsed electric field (PEF) to damage plant cells to obtain bioactive compounds before extraction. However, research into the use of PEF to break down the glandular trichome (GT) cells of patchouli for essential oil extraction is still limited. The purpose of this study was to determine the specific energy input needed to break patchouli leaf GT cells by PEF treatment. Patchouli leaves were harvested at 7 months of age, then treated with PEF. GT cell changes were analyzed using scanning electron microscopy. The results show that treatment with variable frequencies caused GT cell wrinkling and treatments with a variable electric field caused GT cell rupture. Electric field treatment at $\mathrm{E}=133.33 \mathrm{~V} / \mathrm{cm}$ and a PEF exposure time of 2 seconds or $E=116.66 \mathrm{~V} / \mathrm{cm}$ and 3 seconds of PEF exposure resulted in consistent rupture of GT cells. Energy consumption of $0.049 \mathrm{~kJ} / \mathrm{cm}^{3}$ promoted GT cell wall shrinkage and consumption of 0.59 $\mathrm{kJ} / \mathrm{cm}^{3}$ broke GT cell walls.
\end{abstract}

\section{Introduction}

The extraction of plant intracellular compounds and bioactive materials have been reported using solid-liquid extraction methods. One factor that can positively affect the extraction process is the level of cell membrane damage. Physical, chemical, and biological treatments are used to induce cell membrane damage. Pulsed electric fields (PEFs) are considered a promising method for cellular network disruption without influencing cell components. ${ }^{1}$ The specific energy consumption (W) of plant tissue breakage using PEF treatment has been assessed in several studies, usually in the range of $1-15 \mathrm{~kJ} / \mathrm{kg}$. ${ }^{2}$ The extraction of the isoflavonoids daidzein and genistein from soybean requires energy consumption of $1.857 \mathrm{~kJ} / \mathrm{kg}$ and $0.743 \mathrm{~kJ} / \mathrm{kg}$, respectively. ${ }^{3}$ Some researchers have reported that $6.4-16.2 \mathrm{~kJ} / \mathrm{kg}$ is the required energy consumption for effective PEFs in potato, ${ }^{4}$ 0.4$6.7 \mathrm{~kJ} / \mathrm{kg}$ for grape skins, ${ }^{5} 2.5 \mathrm{~kJ} / \mathrm{kg}$ for red beetroot, ${ }^{6} 3.9 \mathrm{~kJ} / \mathrm{kg}$ for sugar beet, ${ }^{7}$ and 10 $\mathrm{kJ} / \mathrm{kg}$ for chicory root. ${ }^{8}$

As noted above, research has been done into cell membrane electroporation methods used for extraction of various useful plant cell components, but studies on patchouli oil have not been performed. ${ }^{9,10}$ The effect of low-energy PEFs (3-10 J/kg) on polyphenol extraction from grape seeds has been assessed. ${ }^{11}$ The specific energy input (W) has been identified as a major parameter in the process of extraction.

The magnitude of the specific energy input needed for cell membrane breakage depends on the cathode-anode distance and the chamber dimensions. Treatments using $32 \mathrm{~kJ} / \mathrm{kg}$ of specific energy for apple juice extraction has been found to increase the yield from $71.1 \%$ to $76.3 \% .^{12}$ The required specific energy input for algae suspension extraction (100 g dry weight per $\mathrm{kg}$ ) is 1 $\mathrm{MJ} / \mathrm{kg}{ }^{13}$ Increasing the electric field strength (E) results in a decrease in the required energy to induce maximum damage.

This study is useful in the essential oil industry for the improvement of product quality and quantity. Information about the optimal electric field intensity and the number of pulses to induce glandular trichome (GT) cell wall partition before initiating the essential oil distillation process could be very useful, as these results can be used to find the minimal energy needed to disrupt membranes for a given sample unit weight. ${ }^{12}$ PEF pretreatment is expected to reduce overall energy consumption in distillation. Thus research into the energy consumption required to induce breakage in GT cells is related to the overall production cost of essential oils, which makes this a very interesting area of study.

\section{Materials and Methods}

\section{Materials}

The patchouli plants used in this study were the Tapaktuan (Aceh) variant and were grown in Kesamben District, Blitar, East Java. Plants were harvested at 7 months of
Correspondence: Sukardi Sukardi, Department of Agricultural Industrial Technology, Faculty of Agricultural Technology, Brawijaya University, Jl. Veteran Malang 65145, East Java, Indonesia.

Tel.: +62.0341.551611 - Fax: +62.0341.565420. E-mail: mazsukardi@gmail.com

Key words: Glandular trichome, patchouli, pulsed electric field, SEM.

Acknowledgements: The authors would thank Brawijaya University and Ministry of Research, Technology and Higher Education Indonesia for supporting this research.

Contributions: SSu, Writing the manuscript, concept and design the research, analysis and interpretation data: SSO, writing the manuscript, drafting of the article, critical revision for content; BDA, writing the manuscript, analysis and interpretation data, final approval; YSI, writing the manuscript, analysis and interpretation data, critical revision for content.

Conflict of interest: the authors declare no potential conflict of interest.

Funding: none.

Received for publication: 11 October 2017. Revision received: 15 December 2017.

Accepted for publication: 15 December 2017.

This work is licensed under a Creative Commons Attribution-NonCommercial 4.0 International License (CC BY-NC 4.0).

CC Copyright: the Author(s), 2019

Licensee PAGEPress srl, Italy

International Journal of Plant Biology 2019; 10:7443 doi:10.4081/pb.2019.7443

age. Leaf cell morphology before and after PEF treatment was observed, with scanning electron microscopy (SEM), especially the GT cells.

\section{Sample preparation for glandular trichome cell observation}

Patchouli leaves were cut into about 1 $\mathrm{cm}^{2}$ pieces and coated with gold using a sputter coater (SC-7620). Leaves in the treatment group were treated with PEFs before being cut and observed using SEM.

\section{Electric field treatments}

The electric field treatment of patchouli leaves with the PEF generator is illustrated in Figure 1. Patchouli leaves were placed in the chamber, in between the cathode and anode, then the generator was turned on. The leaves were treated with variations in electric field strength $(E=33.33$ to 133.33 
$\mathrm{V} / \mathrm{cm}$ ) in Protocol I, with 2 and 3 seconds of PEF exposure at $1000 \mathrm{~Hz}$. Variations in frequency (500 to $2000 \mathrm{~Hz}$ ) were used on leaves in Protocol II with 2 and 3 seconds of PEF exposure and E held constant at 66.67 $\mathrm{V} / \mathrm{cm}$. Treatments were performed three times.

\section{Microscopic analysis}

The shape changes of GT cells in patchouli leaves was observed before and after PEF exposure. Microscopic observations were performed on fresh leaves using a scanning electron microscope (SEM; FEIInspect S25-EDAX).

\section{Energy calculation}

The calculation of the required energy for GT cell breakage was used to estimate the specific energy input required during the electric field strength treatment ${ }^{14}$. The equation for this calculation is:

$\mathrm{W}=\mathrm{U}^{2} \cdot \mathrm{t} \cdot \mathrm{R}_{\mathrm{c}}^{-1} \cdot \mathrm{V}_{\mathrm{c}}^{-1}$,

where $\mathrm{W}=$ energy specific input $\left(\mathrm{kJ} / \mathrm{cm}^{3}\right)$, $\mathrm{U}=$ electric potential $(\mathrm{kV}), \mathrm{t}=$ total time of PEF exposure (s), $R_{c}=$ resistance of the electrode $(\Omega)$ and $V_{c}=$ volume of the chamber $\left(\mathrm{cm}^{3}\right)$.

\section{Statistical analysis}

The experiments were performed three times. Means and standard deviations were calculated. The data were analyzed using one-way ANOVA using SPSS version 17. A $5 \%$ significance level was used for each analysis.

\section{Results}

\section{The number of glandular trichrome} cells

Patchouli oil is produced in peltate glandular trichome cells on both of leaf sides. The density of GT cells is very important for the patchouli plant. The number of GT cells on both of leaf surfaces was approximately $1550 / \mathrm{cm}^{2}$ (Figure 2).

\section{Influence of voltage on GT cell breakage}

The ANOVA model had an $\mathrm{R}^{2}$ was 0.982 , which indicates that $98.2 \%$ of GT cell breakage was affected by the electric field strength (E); the percentage of GT cell damage is shown in Figure 3. At an electric field strength of $33.33 \mathrm{~V} / \mathrm{cm}, 85 \%$ of GT cells were broken at a PEF exposure time of 2 seconds; this increased to $92 \%$ with 3 seconds of PEF exposure. Increased voltage and exposure times to the PEF had a real effect on GT cell damage. PEF-induced damage in the plant tissue is dependent on the electrophysical properties of the cell membrane, such as impedance and capaci- tance. ${ }^{15}$ Irreversible rupture of onion tissue occurs at $333 \mathrm{~V} / \mathrm{cm}$, and the number of ruptured cells increases with increasing frequency and duration of PEF exposure. ${ }^{16}$ In the present study, it was found that $3 \mathrm{sec}$ -

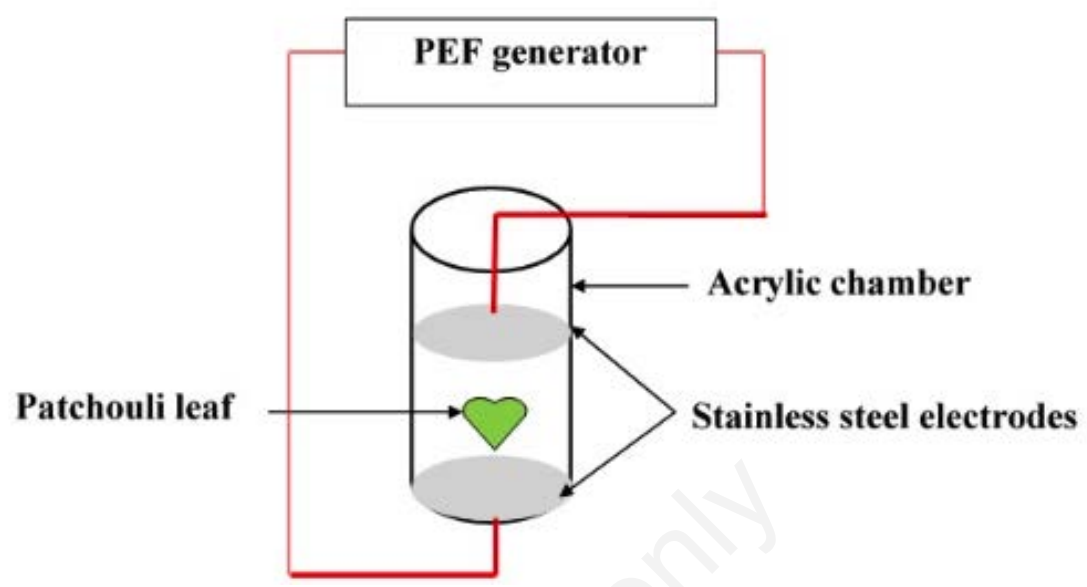

Figure 1. The electric field treatment of patchouli leaves with the PEF generator.

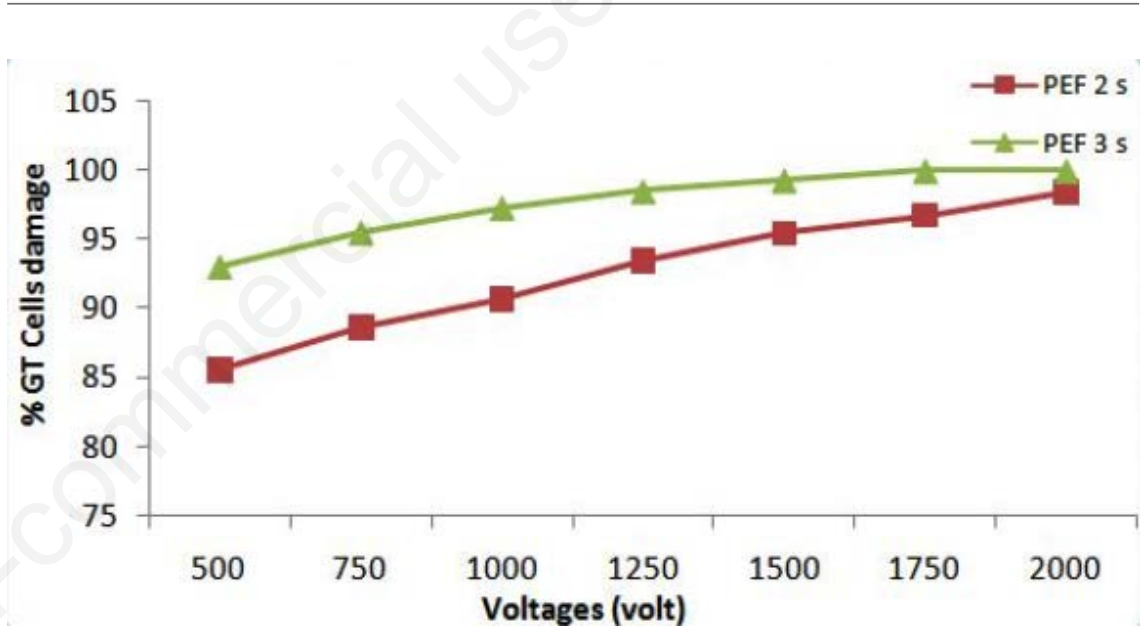

Figure 2. The number of glandular trichrome cells.

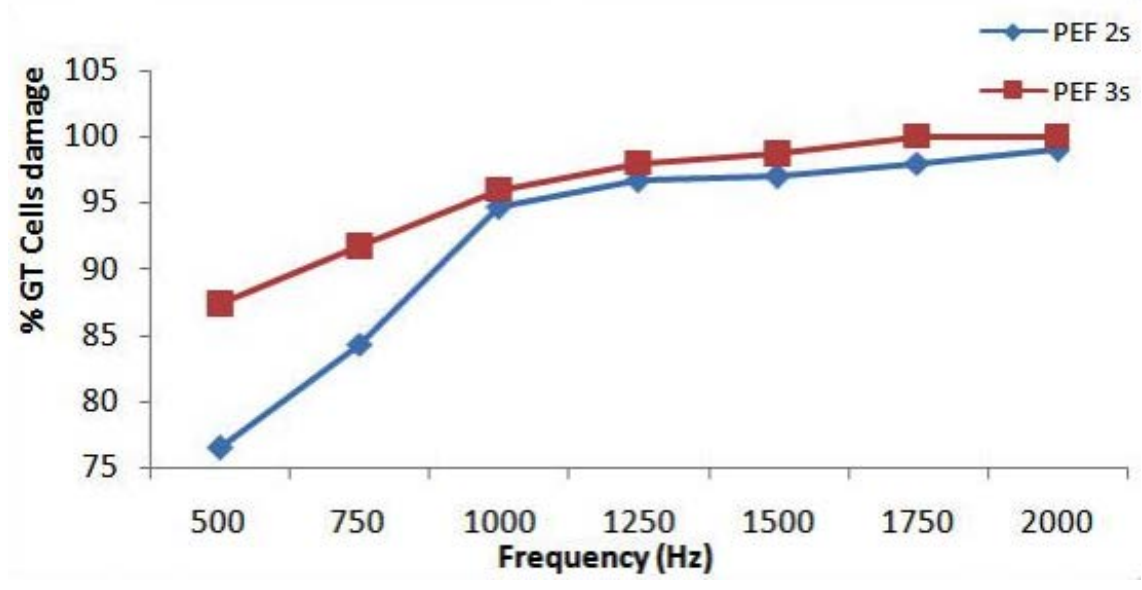

Figure 3. Influence of voltage on GT cell breakage. 
onds of PEF exposure was needed to break all GT cells with an electric field strength of $116.67 \mathrm{~V} / \mathrm{cm}$ (1750 volts), whereas $2 \mathrm{sec}-$ onds of PEF exposure with an electric field strength of $133.33 \mathrm{~V} / \mathrm{cm}$ (2000 volts) caused $99 \%$ of the GT cells to be damaged (Figure 3).

\section{Influence of frequency on GT cell breakage}

The results show that treatment using frequencies above $1000 \mathrm{~Hz}$ has a significant effect on GT cell damage induction; PEF exposure for 2 or 3 seconds did not have a significant difference regarding the effect. Treatment at $2000 \mathrm{~Hz}$ for 2 seconds of PEF exposure with an electric field strength of $33.33 \mathrm{~V} / \mathrm{cm}$ resulted in $99 \%$ GT cell damage, whereas 3 seconds of PEF exposure resulted in $100 \%$ GT cell damage (Figure 4).

\section{Influence of specific energy input on GT cell breakage}

The energy supplied to patchouli leaves during treatment led the tissues to become fragile, which facilitated the extraction of essential oils contained in GT cells. The calculation of the number of broken GT cells is reflected in the specific energy input (W) required for GT cell damage in the chamber. Based on Figure 4, the GT cell shape changed visibly after PEF treatment. Shrinkage and rupture of GT cells were used to calculate the $\mathrm{W}$ that passed through the chamber where the material was exposed to PEF treatment.

The percentage of GT cells damaged due to PEF treatment in patchouli leaves with $\mathrm{W}=0.03 \mathrm{~kJ} / \mathrm{cm}^{3}$ was $85.6 \%$. GT cell damage with $\mathrm{W}=0.29 \mathrm{~kJ} / \mathrm{cm}^{3}$ was $98.5 \%$, and $100 \%$ in material treated with $\mathrm{W}=0.53$ $\mathrm{kJ} / \mathrm{cm}^{3}$. GT cell damage was $93 \%$ after treatment with $0.03 \mathrm{~kJ} / \mathrm{cm}^{3}$ of specific energy input for 3 seconds of PEF exposure and reached $100 \%$ with a specific energy input $\geq 0.26 \mathrm{~kJ} / \mathrm{cm}^{3}$ (Figure 4). Treatments using less than 1 second of PEF exposure at the same specific energy input damaged GT cells in patchouli leaves. Thus, cell damage by PEF treatment required only nanoseconds.

\section{Discussion}

\section{The number of glandular trichrome} cells

The number of GT cells on the lower leaf surface (abaxial) was two-fold higher compared to the upper leaf surface (adaxial), indicating that patchouli leaves have a greater an economic value than other parts of the plant. The density of the GT cells reflects the amount of oil contained, and post-harvest handling of leaves should be done so that the oil is not decomposed and lost. The adaxial side is more frequently exposed to physical influences such as heat, rain and other factors, so the possibility of GT cell damage is greater; damage could lead to evaporation of the essential oil prior to harvest. On the abaxial side, GT cells are more protected so that the amount of oil can be maintained.

\section{Influence of voltage on GT cell breakage}

The critical electric field strength depends on the number of pulses, and PEF treatment may be more efficient if a higher electric field strength is used. ${ }^{17}$ The effect of the electric field strength (E) on GT cells was determined by the change in GT cell shape and patchouli oil components. Patchouli alcohol is the most important component of patchouli oil and alkaline solution ( $\mathrm{pH}$ 6.3-6.8). Cells will burst into a deflated-ball form with negative pole lead tendency after PEF treatment (Figure 5). The relationship between $\mathrm{E}$ and the duration of PEF exposure is a very important factor that can affect the energy received by plant tissue cells. The optimal electric field strength (Eopt) of vegetable tissue depends on the cell network and cell-wall type. ${ }^{18}$ The duration of PEF exposure in plant cells affects the cell wall integrity of plant tissue. ${ }^{19}$

\section{Influence of frequency on GT cell breakage}

The effect of increasing the frequency while treating fresh patchouli leaf GT cells did not cause breakage but rather caused the GT cells to be wrinkled while increasing the voltage caused breakage. The percentage of GT cells damaged at a frequency of $500 \mathrm{~Hz}$ was $76.5 \%$ and $87.3 \%$ after 2 and 3 seconds of PEF exposure, respectively. GT cell dam-

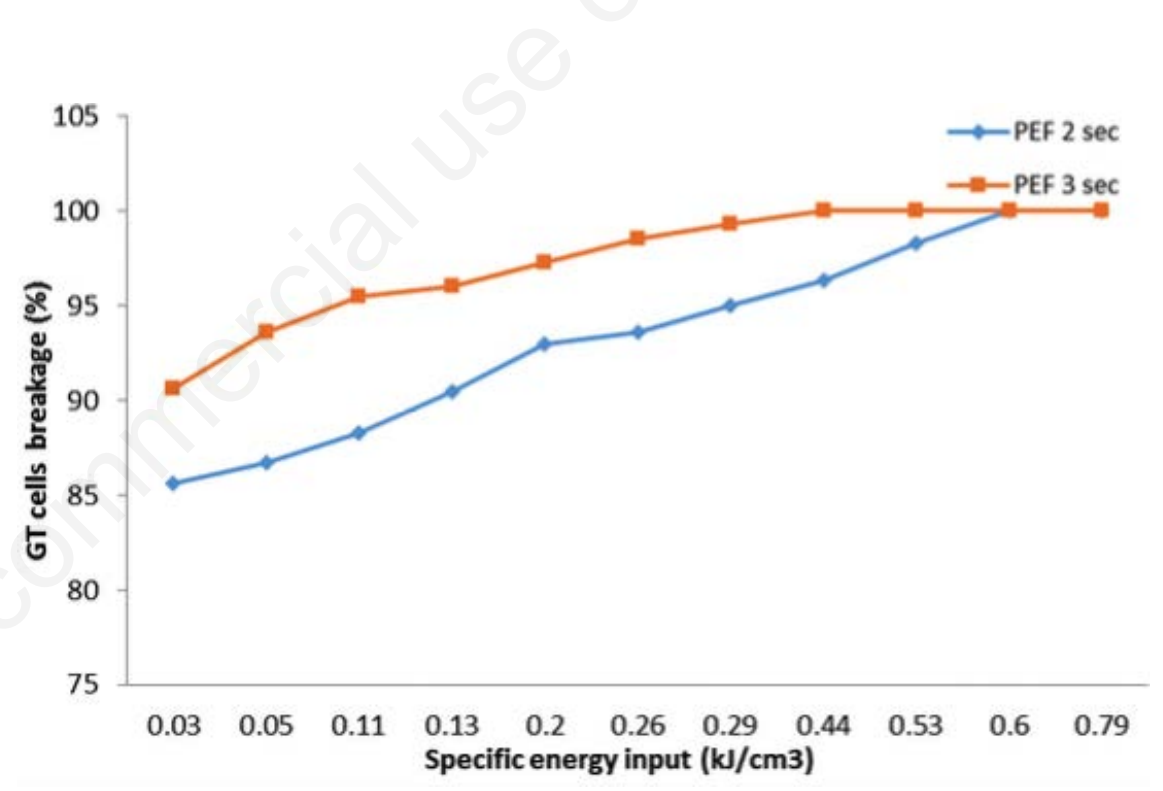

Figure 4. Influence of frequency on GT cell damage.
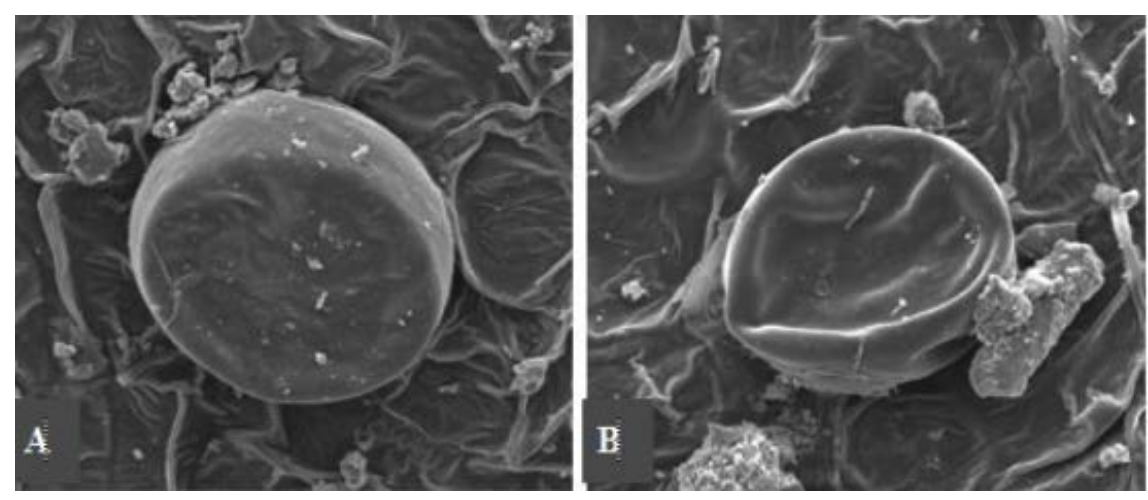

Figure 5. GT cell shape before (A) and after (B) PEF treatment. 
age increased sharply in the frequency range of 500 to $1000 \mathrm{~Hz}$ with 2 and $3 \mathrm{sec}-$ onds of PEF exposure, indicating that damage starts at a low frequency. PEF treatment at a low frequency can increase the rate of tissue permeabilization. ${ }^{20}$ At low frequencies, the GT cell membrane acts as a capacitor to prevent the flow of electrical current into the intracellular medium. After increasing the frequency, the cell membrane becomes less and less resistant to current flow. GT cell damage reached $100 \%$ after treatment at $1750 \mathrm{~Hz}$ with 3 seconds of PEF exposure and an electric field strength of $33.33 \mathrm{~V} / \mathrm{cm}$. The damage levels were $98 \%$ and $99 \%$ when leaves were treated at 2000 $\mathrm{Hz}$ for 2 seconds of PEF exposure.

At a high frequency, the membrane is completely shorted out and the absolute value of the complex impedance is representative of the contribution of both the extracellular and intracellular media (ohmic behavior). Therefore, further tissue damage, caused by external stress due to PEF treatment, can be detected at low frequencies. ${ }^{1}$ Statistical analysis showed that the $\mathrm{R}^{2}$ value was $99.1 \%$, which indicates that frequency has a considerable influence on GT cell damage.

\section{Influence of specific energy input on GT cell breakage}

The treatment of voltage was higher energy yields than the frequency and voltage effect against the GT cell damage also higher. As a consequence of so-called electroporation, this will result in increased permeability of GT cell and increase cell damage. When a higher voltage is used, then the strength of the electric field also increases, as does the amount of energy received by the material. ${ }^{21,22}$ Changes were observed in the structure of GT cells in patchouli leaves following treatment with different specific energy inputs (Figure 6). Mechanical damage to GT cells was greatly affected by parameters such as cell shape and electrode distance, and GT cell volume decreased, influenced by PEF intensity. ${ }^{23}$

Electric field strength (E), specific energy input (W), and temperature (T) have been identified as the major parameters in the process of damage induction. The electric field strength initiates the effects, while the specific energy input can be applied as the parameter dose. The required specific energy input totally depends on the application, e.g., $5-10 \mathrm{~kJ} / \mathrm{kg}$ is needed to increase plant tissue porosity. ${ }^{9}$ The estimated specific energy consumption for the electroporation of apple, carrot, and potato tissue is 400 $\mathrm{V} / \mathrm{cm}^{24}$

The specific energy input (W) required to break down and rupture GT cells in patchouli leaves was $\pm 0.59 \mathrm{~kJ} / \mathrm{cm}^{3}$. The GT cell shape after PEF treatment resembled an exploded ball. The application of PEF to optimize plant tissue rupture is specific for each type of crop and influenced by the plant cell wall structure. The required specific energy input to break down GT cells in patchouli leaves is lower than in apple (7.5 $\mathrm{kJ} / \mathrm{kg}$ ), which correlates with a report by Lebovka et al. $^{25}$ The specific energy input will have an impact on the effectiveness of cell destruction. ${ }^{26}$ PEFs application with a low specific energy input $(\sim 7 \mathrm{~kJ} / \mathrm{kg})$ on betanin extraction from beet tubers provided the highest yield. ${ }^{27}$ Cells were ruptured when treated with a specific energy input of $\sim 0.5 \mathrm{KJ} / \mathrm{cm}^{3}$. The energy required to induce GT cell wrinkling was $\sim 0.1 \mathrm{KJ} / \mathrm{cm}^{3}$. Cell rupture and damage are determined by the voltage, pulse number, and type of treated material. $^{28}$

The cells were damaged due to potential differences inside and outside the cell, known as the trans-membrane potential. ${ }^{29}$ The GT cells of patchouli leaves observed in this study are soft, while the cell walls are made of cellulose. PEF treatment was affected by GT cell damage, the permeability of the electro-membrane, and cell size. ${ }^{22}$

\section{Conclusions}

A specific energy is required to obtain the essential oil so it can be easily extracted from the cells. This study may potentially help in industrial aspects by reducing the time and cost of production and increasing the productivity and income of facilities extracting essential oils or other cell products from P.cablin.

\section{References}

1. Donsi F, Ferrari G. Application of pulsed electric field treatment for the enhancement of mass transfer from vegetable tissue. Food Eng Rev 2010;2: 109-30.

2. Vorobiev E, Lebovka N. Enhanced extraction from solid foods and biosuspensions by pulse electrical energy. Food Eng Rev 2010;2:95-108.

3. Guderjan M, Toefl S, Angersbach A, Knorr D. Impact of pulsed electric field treatment on the recovery and quality of plant oils. Food Eng 2005;67:281-7.

4. Angersbach A, Knorr D. High intensity electric field pulses as pretreatment for affecting dehydration characteristics and rehydration properties of potato cubes. Nahrung-Food 1997;41:194-200.
5. Lopez N, Puertolas E, Condon S, et al. Effects of pulsed electric fields on the extraction of phenolic compounds during the fermentation of must of Tempranillo grapes. Innovative Food Sci Emerg Technol 2008;9:477-82.

6. Lopez N, Puertolas E, Condon S, et al. Enhancement of the solid-liquid extraction of sucrose from sugar beet (Beta vulgaris) by pulsed electric fields. LHW-Food Sci Technol 2009a;42:1674-80.

7. Lopez N, Puertolas E, Condon S, et al. Enhancement of the extraction of betanin from red beetroot by pulsed electric fields. Food Eng 2009b;90:606.

8. Loginova KV, Shynkaryk V, Lebovka $\mathrm{N}$, Vorobiev E. Acceleration of soluble matter extraction from chicory with pulsed electric fields. Food Eng 2010;96:374-9.

9. Toefl S. Pulsed electric field food treatment-scale up from lab to industrial scale. International Congress on Engineering and Food (ICEF11), Germany 2011:776-9.

10. Cerdan G, Arenzana LG, Lopez N, et al. Effect of different pulsed electric field treatments on the volatile composition of Graciano, Tempranillo and Grenache grape varieties. Innov Food Sci and Emerg Technol 2013;20:91-9.

11. Zderic A, Zondervan E, Meuldijk J. Breakage of cellular tissue by pulsed electric field: extraction of polyphenols from fresh tea leaves. ChemEng Trans 2013;105:357-66.

12. Turk MF, Vorobiev E, Baron A. Improving apple juice expression and quality by the pulsed electric field on an industrial scale. LWH-Food Sci Technol 2012;49:245-50.

13. Goettel M, Eing C, Gusbeth C, et al. Pulsed electric field assisted extraction of intracellular valuables from microalgae. Alga Res. 2013;2:401-8.

14. Zhang QH, Barbosa-Canovas G, Swanson B. Engineering aspects of pulsed electric field pasteurization. Food Eng 1995;25:261-81.

15. Lamanauskas N, Bobinaite R, Satkauskas S, et al. Pulsed electric field assisted juice extraction of frozen/thawed blueberries. Zemdirbyste-Agriculture 2015;102:5966.

16. Ersus S, Barrett D. Determination of membrane integrity in onion tissue treated by pulsed electric field: use of microscopic images and ion leakage measurement. Innovative Food Sci and Emerg Technol 2010;11:598-603.

17. Asavasanti S, Ersus S, Ristenpart W, 
Stroeve P, Barrett D. Critical electric field strengths of onion tissues treated by pulsed electric fields. Food Sci 2010;75:E433-43.

18. Bazhal M, Lebovka N, Vorobiev E. Optimisation of pulsed electric field strength for electroplasmolysis of vegetable tissues. Biosys Eng 2003;86:33945.

19. Bazhal M, Ngadi M, Raghavan V. Influence of pulsed electroplasmolysis on the structure of apple tissue. Biosys Eng 2000;86:51-7.

20. Asavasanti S, Stroeve P, Barrett DM, et al. Enhanced electroporation in plant tissue via low frequency pulsed electric field: influence of cytoplasmic streaming. Biotechnol Prog 2011;28:445-53.

21. Kulshrestha S, Sastry S. Frequency and voltage effect on enhanced diffusion during moderate electric field (MEF) treatment. Innovative Food Sci Emerg Technol 2003;4:189-94.

22. Liu ZW, Zeng X, Sun DW, Han Z. Effects of the pulsed electric field on the permeabilization of calcein-filled soybean lecithin vesicles. Food Eng 2014;131:26-32.

23. Janositz A, Knorr D. Microscopic visualization of pulsed electric field induced change on plant cellular level. Innovative Food Sci Emerg Technol 2011;11:592-7.

24. Lebovka NI, Bazhal M, Vorobiev E. Estimation of characteristic damage time of food materials in pulsed electric field. Food Eng 2002;54:337-46.

25. Lebovka NI, Mhemdi H, Grimi N, et al. Treatment of potato tissue by pulsed electric fields with time-variable strength. Theoretical and experimental analysis. Food Eng 2014;137:23-31.
26. Heinz V, Toepfl S, Knorr D. Impact of temperature on lethality and energy efficiency of apple juice pasteurization by pulsed electric fields treatment. Innov Food Sci Emerg Technol 2003;4:167-75.

27. Fincan M, DeVito F, Dejmek P. Pulsed electric field treatment for solid-liquid extraction of red beetroot pigment. Food Eng 2004;64:381-8.

28. Praporscic I, Muravetchi V, Vorobiev E. Constant rate expressing of juice from biological tissue enhanced by pulse electric field. Drying Technol 2004;22:2395-408.

29. Jiahui L, Xinlao W, Yonghong W, Gongqiang L. Analysis for relationship of transmembrane potential-pulse electric field frequency. Food Bioprod Process 2009;87:261-5. 